\title{
Regional Identity and Cultural Landscapes
}

\section{for Sustainability of Ecotourism}

\section{from Tourist Perspectivesin DüzceUğursuyu and Aksu Watersheds}

\author{
Pınar GÜLTEKIN-Osman UZUN-YaşarSelman GÜLTEKIN-Sinem ÖZDEDE-Sertaç KAYA \\ Duzce University Faculty of Forestry 81620 Konuralp Campus Duzce/TURKEY \\ E-mail address: \\ pinargultekin@duzce.edu.tr,osmanuzun@duzce.edu.tr,selmangultekin@duzce.edu.tr, \\ sinemozdede@duzce.edu.tr, sertackaya@duzce.edu.tr
}

\begin{abstract}
Cultural landscape is a concept that emerges from people who live in the geographical area where they belong, by changing their natural landscapes and reflecting their own characters.Thus, cultural landscapes can be interpreted as a symbol that reflects the values, philosophy, history and government of that community. The diversity of natural and cultural values at the local and regional scale contributes to the formation of regional identity. Cultural landscapes can also be considered as a sign and source of regional identity. It is not enough to have only natural resources for a tourism destination in ecotourism planning. An area containing in historical, architectural, social and cultural identity contributes to its original values by reducing the chance of imitating an area for ecotourism sustainability.

In this study, it was aimed to determine the opinions of the ecotourists who have the potential to visit Ugursuyu and Aksuwatersheds, to determine the extent to which user demands and expectations influence cultural landscapes; and to bring proposals for the protection and development of regional identities. Surveys were carried out on the tourists and daily visitors in the Akçakoca and Karasu Coast bands, Sapanca Lake and Abant Nature Park, which are daily trips to Istanbul and Ankara metropolises. Within this scope, 240 surveys were applied to the tourists and visitors who came to the mentioned areas. 207 surveys were accepted as valid. In the evaluation of the
\end{abstract}


applied surveys, 'SPSS 22 ' statistical package program was used. In the analysis; frequency, and one-way anovaanalysis were applied. In the survey, questions were asked about how participants attended to information about demographics, destination preferences, how they had previously participated in ecotourism activity, where they participated in ecotourism activity, how preferences of locality-specific values affected their preferences and also were tried to evaluate visitor loyalty. On the back of the survey, 20 photographs reflecting the natural and cultural landscape elements of Uğursuyuwatershed (13) and Aksu watershed (7) are evaluated in $1,2,3,4,5$-point intervals in terms of adjective pairs such as pleasant-unpleasant, interesting-boring, safe-unsafe...

As a result of the survey, tourists preferred areas that offer accommodation and activities where local elements and local people are located, but they did not choose natural areas. They only stated that they could visit the region with the aim of seeing cultural values. According to the results of the obtained data, the conflict between the conservation of cultural landscapes and the evaluation of ecotourism activities was evaluated in the study area, and suggestions on the development of regional identity and the sustainability of ecotourism activities are brought forward.

Keywords:Cultural Landscape, Düzce, Ecotourism, Regional Identity, Sustainability

\section{Introduction}

According to Lynch (1960), identity is all of the properties that created by nature or manufactured by human beings be distinguished from similar ones (Önem, 2004). Identity is a cultural and social phenomenon. Culture, which is an element of identity, is a very broad concept which covers the tradition, life-style, customs, habits of the society (Beyhan and Ünügür, 2005).Especially, the developments in communication technology, instead of making integrative effect, have accelerated the process of getting people aware of their ethnic, religious and national identities and identifying them. In this context, the concept of protection of cultural identity has started to gain importance (Duran, 2011).

The cultural level of a society is an important factor in identifying and directing the identity of the individuals who form the society (Beyhan and Ünügür, 2005). Interactions between the unique properties of the region and all the other components play an effective role in the region-specific identity formation (Çalışkan, 2013). Places that stand out from the differences and changes created by the 
landscape character type of the region in their own cultural backgrounds in different regions of a country, provide an existence of regional identity and cultural landscape pattern (Uzun et.al 2016).

The increase in attractiveness and preferability of touristic areas increases in the direct proportion to the original cultural landscapes and local identities (Gültekin and Gültekin, 2018). Studies on the relationship between tourism and identity reveal that the search for local culture and identity in tourist preferences has begun to come to the forefront (Mellinger 1994; Duran 2011). Tourism destinations are increasingly similar to each other due to globalization (Ooi, 2004). This situation decreases the attractiveness of tourism destinations in an increasingly competitive environment and forces them to create differences (HavenTang and Jones 2006; Çalışkan 2013).

In recent years, touristic trips have been organized in order to recognize the life in different cultures and these activities have been usually collected under the title of ecotourism. Properties of the ecotourism is a type of tourism that coming from natural history, including local cultures, and ecotourists visit the natural areas without consuming natural resources and make an effort to protect these areas (Ziffer 1989).

The preservation of the regional identity of tourism destinations, sustainability of cultural heritage and landscapes depends on the preference of ecotourism instead of mass tourism. The application and sustainability of ecotourism is related to the extent to which regional identity and cultural landscapes are preserved and attracted by tourists. The sustainability of ecotourism and regional identity are in a mutual interaction.

In this study, it was aimed to determine the opinions of the ecotourists who have the potential to visit Uğursuyu and Aksuwatersheds, to determine the extent to which user demands and expectations influence cultural landscapes, and to bring proposals for the protection and development of regional identities.

\section{Methods}

In this study, a survey was developed to determine the opinions of ecotourists who have the potential to visit Uğursuyu and Aksuwatersheds and to determine their demands and expectations.As in some studies (such as Roovers et al. (2003), Akten (2003), MüderrisoğluveUzun (2004), Bulut (2006) Kıroğlu (2007), Özhancıve Yılmaz (2013), Özhancıve Yılmaz (2012)), user surveys were applied in many studies including the concepts of visual landscape analysis and recreation area. The study area is rich in 
natural and cultural landscape elements. Although study area is a day-long distance to Istanbul and Ankara metropolises; it is not a preferred area by tourists on the contrary of Akçakoca, Karasu, Sapanca and Abant (Fig. 1).
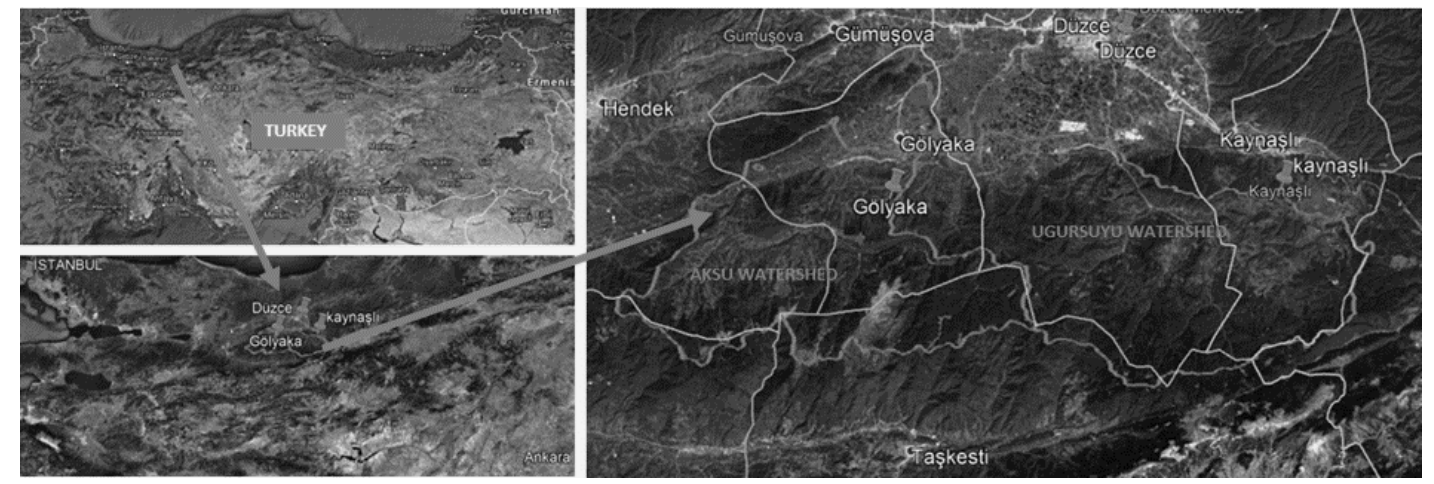

Figure 1. Location of the study area.

Akcakoca, Karasu, Sapanca and Abant destinations were selected as points where surveys will be carried out because they are frequented by tourists coming from Ankara and Istanbul. For this reason, a survey was developed by the tourists who came to these areas in order to determine their consideration for Uğursuyu and Aksuwatersheds. The survey data were collected through survey forms using the convenience sampling method and interview technique.

On the front of the survey; the reasons for the participants for choosing the area, the type of destination they prefer, whether they participated in the ecotourism activity in Düzce or not, and which activities they had participated were asked. On the back of the survey, there were photo evaluations of Uğursuyu and Aksuwatersheds. In order to determine the photographs used in the survey, a total of 425 photographs were taken from both watersheds. While taking photos, it was taken into consideration that the air was open and there were no negative elements affecting the human perception. In addition, subjective photo shoots that may affect the outcome of the study were avoided. The photographs were selected to reflect the possibilities of ecotourism in the Uğursuyu and Aksuwatersheds, also to reflect the problems of the areas which may cause pressure on ecotourism such as hydroelectric power plant, hazelnut fields, damaged areas. These photographs were evaluated by 3 landscape architects and 1 forest engineer and it was reduced to 20 photographs, including 13 on the Uğursuyuwatershed and 7 on the Aksu watershed. In the selection of photographs, 
it was taken care to select the photographs reflecting the general character of the watersheds.

In total, 3 pairs of adjectives and 5-point Likert-type scale was used in the evaluation of the 20 photographs by the visitors. Previous studies (Özgüç 1999, Kıroğlu 2007, Özhancl and Yılmaz 2011, Müderrisoğlu and Gültekin 2013) were used to determine these adjective pairs and the scale. Adjective couples were identified as pleasant-unpleasant, interesting-boring, safe-unsafe. The 3 adjective pairs mentioned in the method are based on the evaluation of the visual landscape quality. In this context, 240 surveys were carried out for tourists and visitors who came to these areas and 207 surveys were accepted as valid. SPSS 22 statistical package program was used to evaluate the applied surveys. In the analyzes, the mean value was taken and it was explained by One-Way Variance Analysis. According to the results, the conflict between the conservation of cultural landscapes and evaluation of ecotourism activities was evaluated, proposals for the development of regional identity and the sustainability of ecotourism activities were brought forward in the study area.

\section{Results and Discussion}

The findings of the respondents who visited to the Akçakoca, Karasu, Sapanca and Abant destinations to determine the likes of the Uğursuyu and Aksu watersheds are presented in this section.

Table 1 shows the area in which the survey is conducted, the reasons of the participants to choose the area, the frequency and percentage values of the properties of the destinations.

Table 1. Assessments on Destination Preferences

\begin{tabular}{|c|c|c|c|}
\hline \multirow{4}{*}{ RESPONSE } & NUMBER & PERCENT \\
\cline { 2 - 4 } & Karasu & 53 & 23,6 \\
\cline { 2 - 4 } & Akçakoca & 53 & 23,6 \\
\cline { 2 - 4 } & Abant & 48 & 23,2 \\
\cline { 2 - 4 } & Sapanca & 53 & 23,6 \\
\cline { 2 - 4 } & Total & 207 & 100 \\
\cline { 2 - 4 } & Media, Advertisement, Announcement & 7 & 3.3 \\
\cline { 2 - 4 } & Tourism Fairs and Conferences & 1 & 0.4 \\
\hline
\end{tabular}


5th International Conference on Civil Engineering,Architecture and Urban Planning Elites

\begin{tabular}{|c|c|c|c|c|}
\hline \multirow{6}{*}{$\begin{array}{c}\text { Reason for } \\
\text { Preferring the } \\
\text { Area }\end{array}$} & \multicolumn{2}{|c|}{ Recommendation of Incoming Visitors } & 83 & 40 \\
\hline & \multicolumn{2}{|l|}{ Internet } & 8 & 3,9 \\
\hline & \multicolumn{2}{|l|}{ Travel agency } & 20 & 9.7 \\
\hline & \multicolumn{2}{|l|}{ I've been before } & 76 & 36,8 \\
\hline & \multicolumn{2}{|l|}{ My preference } & 12 & 5.9 \\
\hline & \multicolumn{2}{|l|}{ Total } & 207 & 100 \\
\hline \multirow{24}{*}{$\begin{array}{l}\text { Properties of } \\
\text { their preferred } \\
\text { destination }\end{array}$} & \multirow[t]{5}{*}{ Water Elements } & Sea & 91 & 43,9 \\
\hline & & Stream & 0 & 0 \\
\hline & & Lake & 22 & 10,6 \\
\hline & & Waterfall & 12 & 5,7 \\
\hline & & Total & 125 & 60,7 \\
\hline & \multirow[t]{5}{*}{ Flora } & Forest & 47 & 22,6 \\
\hline & & Highland & 23 & 11,1 \\
\hline & & One Tree & 0 & 0 \\
\hline & & $\begin{array}{l}\text { Rare Plant Species } \\
\text { Presence }\end{array}$ & 0 & 0 \\
\hline & & Total & 70 & 33,7 \\
\hline & \multirow[t]{5}{*}{ Topography } & Mountain & 10 & 4,5 \\
\hline & & Valley & 0 & 0 \\
\hline & & Plain & 0 & 0 \\
\hline & & Cave & 0 & 0 \\
\hline & & Total & 10 & 4,5 \\
\hline & \multirow{6}{*}{$\begin{array}{l}\text { Cultural } \\
\text { Structure }\end{array}$} & Festival and Carnival & 1 & 0,4 \\
\hline & & $\begin{array}{l}\text { Traditional Village } \\
\text { Settlement }\end{array}$ & 0 & 0 \\
\hline & & Historic pattern & 1 & 0,4 \\
\hline & & Local Foods & 0 & 0 \\
\hline & & Handicraft Products & 0 & 0 \\
\hline & & Total & 2 & 0,9 \\
\hline & \multirow[t]{3}{*}{ Other } & Transportation & 0 & 0 \\
\hline & & Less costly & 0 & 0 \\
\hline & & Total & 207 & 100 \\
\hline
\end{tabular}


According to Table $1 ; 23.6 \%$ of the respondents (53 persons) Karasu, 23.6\% (53 people) Akçakoca, 23.6\% (53 people) Sapanca and 23.2\% as Abant are shown of distribution.When evaluated the reasons for the participants to prefer the area they came for tourism purposes, it wasfound that $40 \%$ ( 83 people) came on the recommendation of the previous ones; travel agency, $5.9 \%$ (12 people) own preference, 3.9\% (8 people) reached the field information on the internet, 3.3\% (7 people) had information about the area with tourism fairs, $04 \%$ ( 1 person) came to the area through media advertisements.

The recommendation behavior is one of the most effective ways of marketing for a destination (Sevim et al. 2013). According to Özdemir (2007); the comments of close relatives, spouses, friends and acquaintances about the destination are extremely important in choosing a destination as a holiday destination. The reliability of information that people getting from social environment is more reliable than other sources. A second important result is that those who have come to the area before, tend to come back again. The concepts of visitor loyalty and advice are associated with the image of the destination (Baloğlu and Mangaloğlu 2001; Chen and Tsai 2007; Inan 2011; Som et al. 2011; Sevim et al. 2013).

According to the preferred destination of the survey participants; $43.9 \%$ (91 people) sea, $22.6 \%$ ( 47 people) forest, $11.1 \%$ ( 23 people) highland, $10.6 \%$ ( 22 people) lake, 5.7\% (12 people) waterfall,\% 4.5 (10 people) mountain, $0.4 \%$ (1 person) festival and carnival, $0.4 \%$ of the historic patternas of distributed. The fact that the tourists participating in the survey most preferred sea-based destinations shows that sea-sand-sun tourism still maintains its importance.The evaluations of the participants about the ecotourism experiences are indicated in Table 2.

Table 2. Ecotourism experiences of the respondents

\begin{tabular}{|c|l|c|c|}
\hline \multirow{4}{*}{\begin{tabular}{c} 
Previously Participated or not $\begin{array}{c}\text { RESPONSE } \\
\text { in Ecotourism Activities in }\end{array}$ \\
\cline { 2 - 4 } Uğursuyu and Aksu Watersheds
\end{tabular}} & Yes & NUMBER & PERCENT \\
\cline { 2 - 4 } & No & 92 & 44,4 \\
\cline { 2 - 4 } & Total & 207 & 55,6 \\
\hline \multirow{4}{*}{} & Rafting & 4 & 400 \\
\cline { 2 - 4 } & Paintball & 39 & 8,7 \\
\cline { 2 - 4 } & Hiking & 43 \\
\hline
\end{tabular}




\begin{tabular}{|c|c|c|c|}
\hline \multirow{5}{*}{$\begin{array}{c}\text { If yes, the event of the } \\
\text { participation }\end{array}$} & Horse Riding & 0 & 0 \\
\hline & Picnic & 40 & 44 \\
\hline & Orienteering & 0 & 0 \\
\hline & Camping & 0 & 0 \\
\hline & Total & 92 & 100 \\
\hline \multirow{7}{*}{ Participated Place } & Efteni Lake & 17 & 18,4 \\
\hline & Aydınpınar & 11 & 12 \\
\hline & SamandereWaterfall & 33 & 35,8 \\
\hline & GüzeldereWaterfall & 25 & 27,1 \\
\hline & KardüzHighland & 6 & 6,7 \\
\hline & Culture Park Recreation Area & 0 & 0 \\
\hline & Total & 92 & 44,4 \\
\hline \multirow{4}{*}{$\begin{array}{l}\text { Whether people will participate } \\
\text { in the ecotourism activity for the } \\
\text { cultural pattern of Ugursuyu and } \\
\text { Aksuwatersheds }\end{array}$} & Yes & 193 & 93,2 \\
\hline & No idea & 11 & 5,4 \\
\hline & No & 3 & 1,4 \\
\hline & Total & 207 & 100 \\
\hline
\end{tabular}

As indicated in Table 2, 44.4\% (92 persons) of the participants had participated in ecotourism activities in DüzceUğursuyu and Aksu watersheds, and 55.6\% (115 persons) had not been participated. In Uğursuyu and Aksu watersheds, the percentage of tourists who participated in and did not participate in ecotourism activities is very close to each other. Tourists have come to areas such as Sapanca and Abant where quite close to the study area, however they do not have any idea about the areas such as Samandere and Güzeldere Waterfalls, Efteni Lake etc. and this number is above the expectation. This situation is thought to be due to the lack of publicity and marketing related to the study area.

Those who participated in ecotourism activities in the Uğursuyu and Aksu watersheds respectively gave $44 \%$ (40 people) picnic, 43\% (39 people) nature walk, $8.7 \%$ ( 8 people) paintball, $4.3 \%$ (4 people) rafting responses. The most visited places in the Uğursuyu and Aksu watersheds were respectively 35.8\% (33 people), 35.8\% (25 persons) Güzeldere Waterfall, 18.4\% (17 people) Efteni Lake, 11\% (12 people) Aydınpınar, 6.7\% (6 people) determined as Kardüz Highland.

The tourists, who had previously experienced the study area, visited the Samandere waterfall, Güzeldere waterfall, Efteni Lake and participated in hiking and 
picnic activities in these areas. Ecotourism destinations are the most prominent areas within the study area but they are limited only by picnic and hiking activities.In the catalog of "Düzce Nature hiking trails (2012)"; Efteni Lake-Güzeldere Waterfall, Güzeldere Waterfall-BalıklıHighland, Aksu Stream-KardüzHighland, TopukHighland-Abant, Samandere Waterfall-Abant, Derdin-ŞehirliHighland-Beyköy-Samandere Waterfall, OdayeriHighland-TorkulPond, Odayeri-DerebalıkHighland, Güzeldere-Efteni and Samandere-Abant trails are known and preferred as determined the results.The attraction of the areas should be increased with the activities such as orienteering, photo safari, botanical tourism etc.

In the future, the responses to the question of whether or not to participate in cultural-oriented ecotourism activities in the Uğursuyu and Aksu watersheds; 93.2\% (193 people) yes, 5.4\% (11 people) no idea, 1.4\% (3 people) no. The respondents were briefly informed about the study area and the purpose of the study, and after evaluating 20 area photographs, they stated that they wanted to participate in ecotourism activities in Uğursuyu and Aksu watersheds. According to Yosmaoğlu and Engin (2002); The development of tourism in a region depends on the effective availability of natural, historical and cultural assets in domestic and foreign markets. If the touristic potentials of the Uğursuyu and Aksu watersheds are promoted, the number of tourists who will prefer these areas will increase.

During the survey, 20 photographs of the area were shown. The participants were briefly informed about the study and the scoring method was explained, and each photograph was evaluated in terms of 3 criteria within 60 seconds on average. For each photo (1 lowest-5 highest; the value of pleasant, interesting, safe) in the range of $1,2,3,4,5$, scoring was done. The photograph included in the survey is shown in Figure 2. 


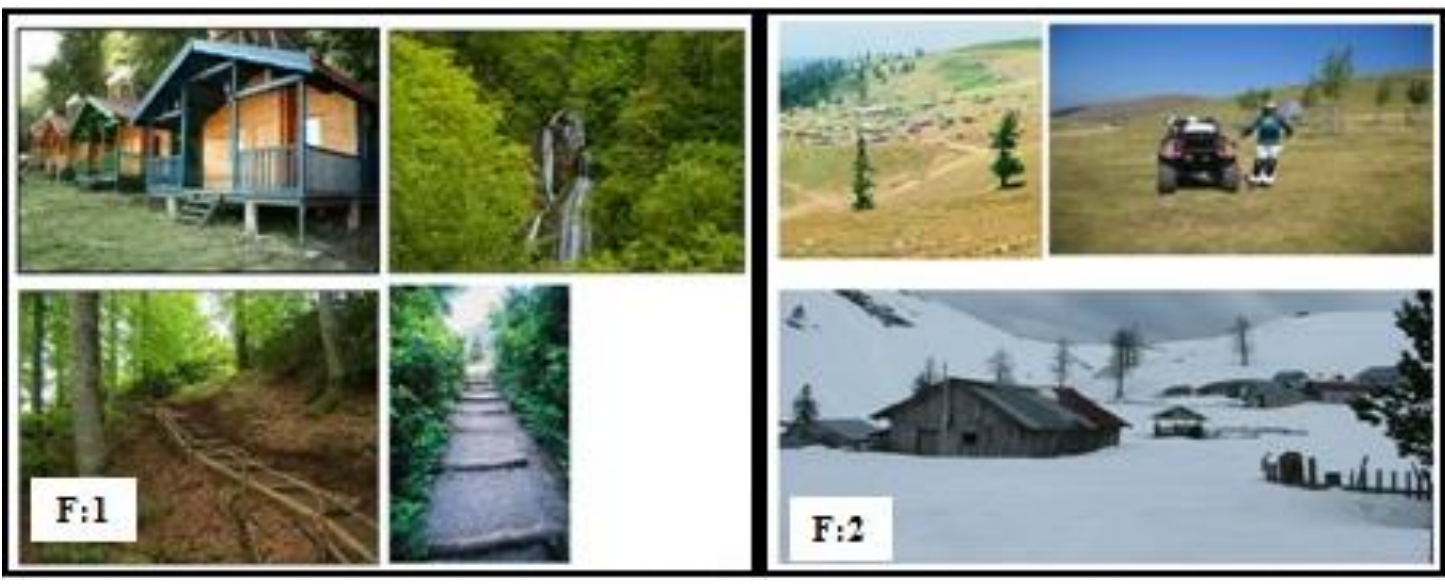


5th International Conference on Civil Engineering,Architecture and Urban Planning Elites Paris, France

November 2-4, 2018

(.....continuing) 

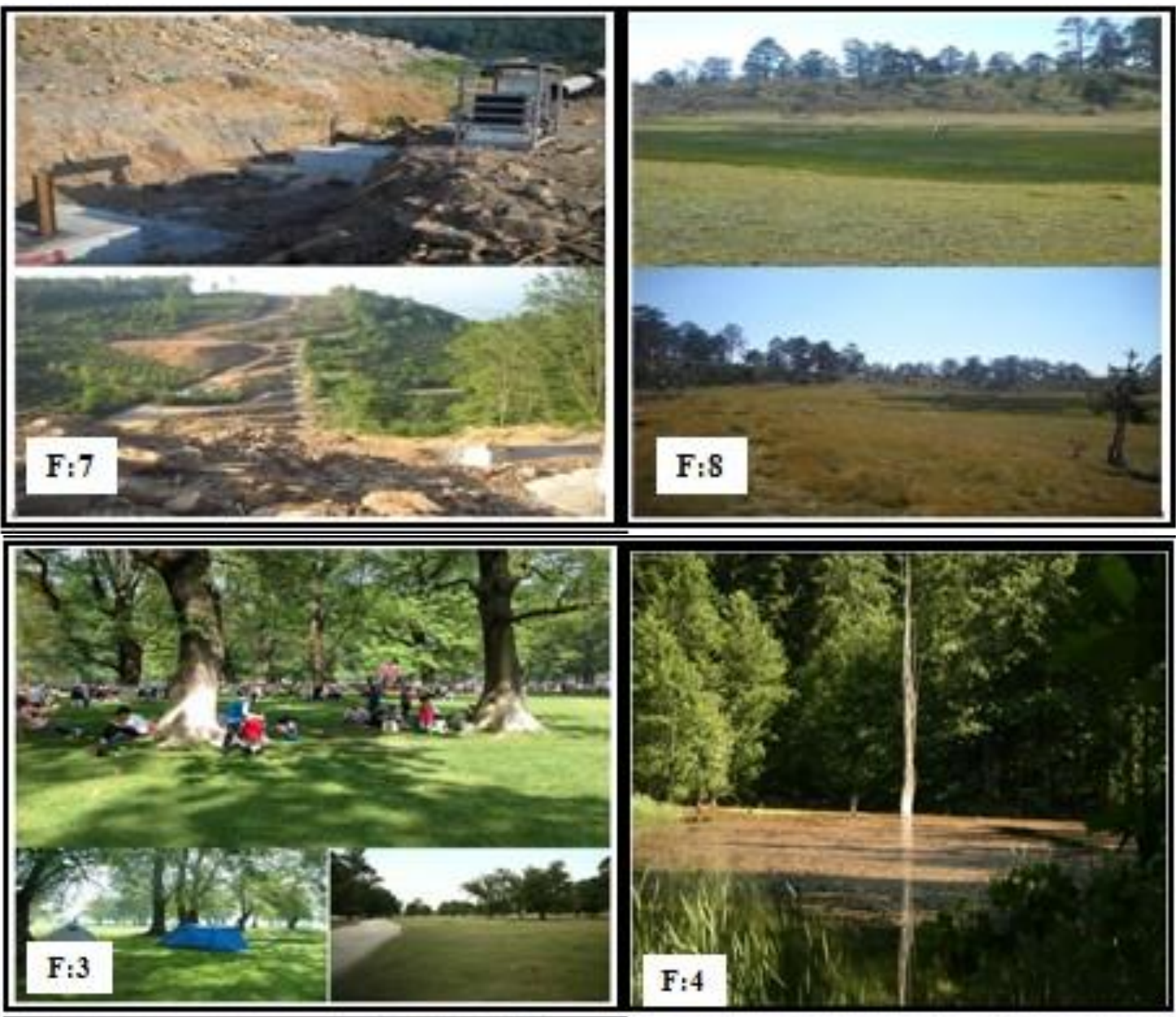
5th International Conference on Civil Engineering,Architecture and Urban Planning Elites Paris, France

November 2-4, 2018

(.....continuing) 
5th International Conference on Civil Engineering,Architecture and Urban Planning Elites Paris, France
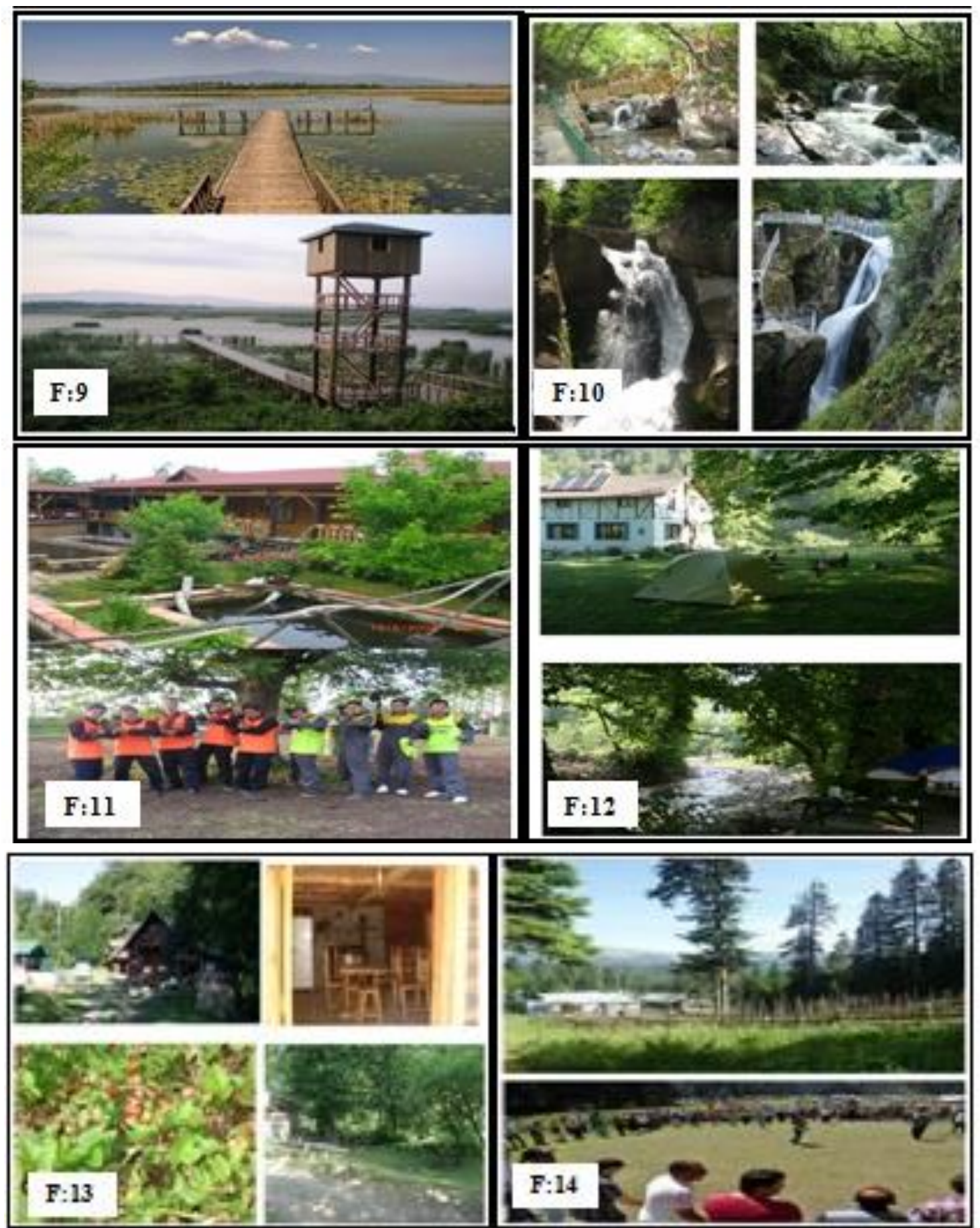

(.....continuing) 
5th International Conference on Civil Engineering,Architecture and Urban Planning Elites Paris, France

November 2-4, 2018
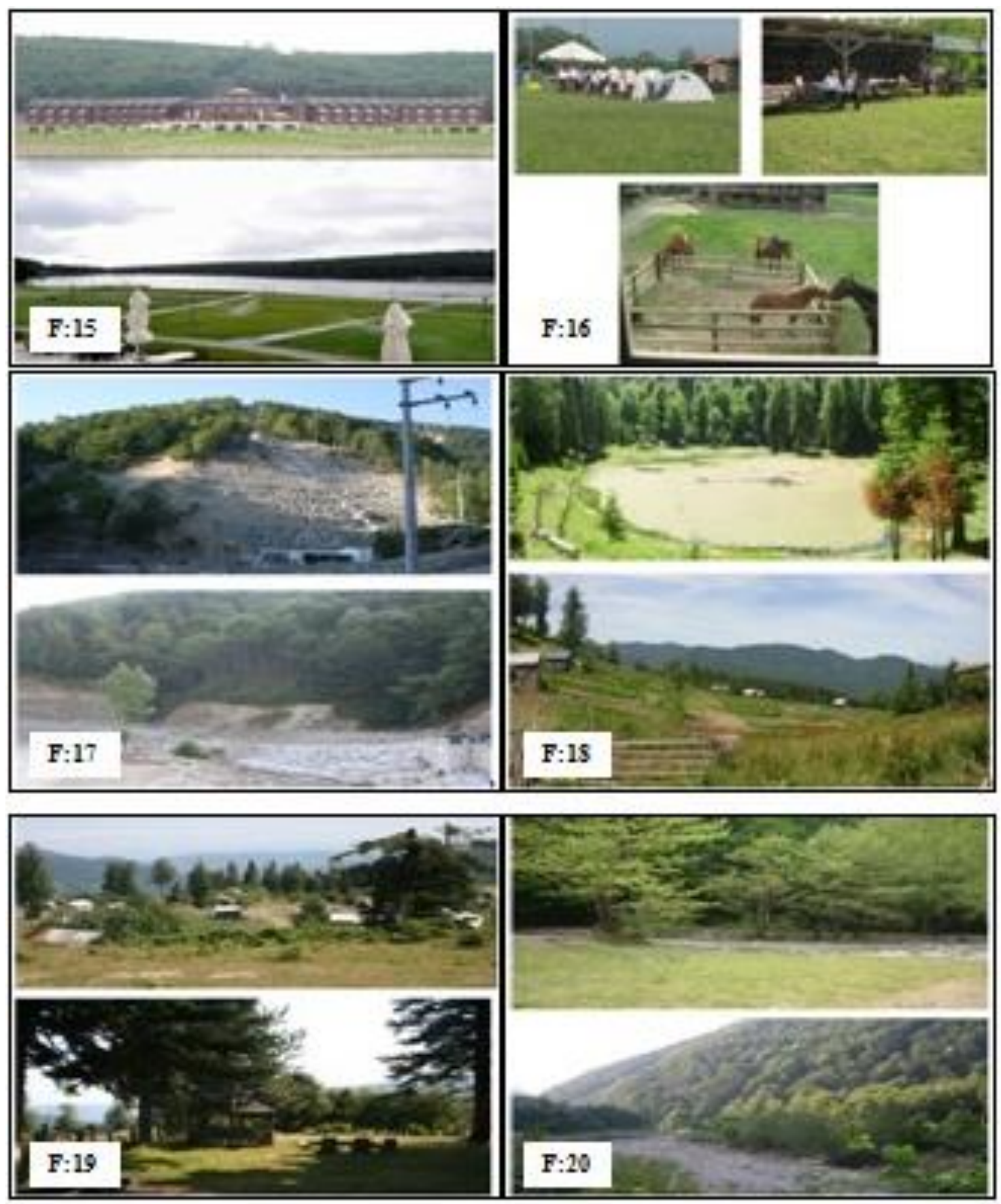

Figure 2.Survey Photos (F1: GüzeldereWaterfall, F2: KardüzYaylası,F3:GölyakaCulture Park,F4:Karagöl,F5: PürenliHighland, F6: Aksu Creek, F7: Aksu HEPP,F8:Sarıgöl,F9:EfteniLake,F10:SamandereWaterfall,F11:Aydınpınar,

F12:Şimşirlik,F13:Derinoba,F14:SinekliHighland, F15:TopukHighland,F16:KonaklıHorse Farm,F17:Uğursuyu HEPP,F18:TorkulPond,F19:Odayeri,F20:Uğurderesiedge) 
The preferences of the tourists in the survey are shown in Table 3.

Table3.Average Values of Tourist Preferences

\begin{tabular}{|l|l|r|r|r|r|r|r|}
\hline \multirow{2}{*}{$\begin{array}{l}\text { Photo } \\
\text { Number }\end{array}$} & \multirow{2}{*}{ Number } & \multicolumn{2}{|c|}{ Pleasant-Unpleasant } & \multicolumn{2}{|c|}{ Interesting-Boring } & \multicolumn{2}{|c|}{ Safe-Unsafe } \\
\cline { 3 - 9 } & & Average & $\begin{array}{r}\text { Standard } \\
\text { Deviation }\end{array}$ & Average & $\begin{array}{r}\text { Standard } \\
\text { Deviation }\end{array}$ & Average & $\begin{array}{l}\text { Standard } \\
\text { Deviation }\end{array}$ \\
\hline 1 & 207 & 4,66 & 0,55 & 4,48 & 0,71 & 4,31 & 0,72 \\
\hline 2 & 207 & 4,45 & 0,73 & 4,28 & 0,89 & 4,49 & 0,78 \\
\hline 3 & 207 & 4,45 & 0,77 & 4,33 & 0,85 & 4,50 & 0,70 \\
\hline 4 & 207 & 4,54 & 0,76 & 4,50 & 0,81 & 4,23 & 1,15 \\
\hline 5 & 207 & 4,42 & 0,78 & 4,43 & 0,84 & 4,24 & 0,83 \\
\hline 6 & 207 & 4,42 & 0,81 & 4,28 & 0,86 & 4,15 & 0,98 \\
\hline 7 & 207 & 1,44 & 0,91 & 1,45 & 0,91 & 1,32 & 0,81 \\
\hline 8 & 207 & 3,20 & 1,06 & 3,17 & 1,07 & 3,14 & 1,02 \\
\hline 9 & 207 & 4,58 & 0,57 & 4,52 & 0,79 & 4,18 & 0,87 \\
\hline 10 & 207 & 4,75 & 0,43 & 4,60 & 0,67 & 4,37 & 0,80 \\
\hline 11 & 207 & 4,59 & 0,59 & 4,63 & 0,59 & 4,56 & 0,67 \\
\hline 12 & 207 & 4,47 & 0,68 & 4,50 & 0,77 & 4,37 & 0,83 \\
\hline 13 & 207 & 4,61 & 0,60 & 4,65 & 0,70 & 4,57 & 0,65 \\
\hline 14 & 207 & 4,61 & 0,70 & 4,23 & 0,88 & 4,43 & 0,69 \\
\hline 15 & 207 & 4,54 & 0,65 & 4,61 & 0,72 & 4,68 & 0,66 \\
\hline 16 & 207 & 4,56 & 0,84 & 4,46 & 0,82 & 4,43 & 0,82 \\
\hline 17 & 207 & 1,43 & 0,92 & 1,42 & 0,88 & 1,42 & 1,01 \\
\hline 18 & 207 & 3,40 & 1,21 & 3,22 & 1,08 & 3,37 & 1,08 \\
\hline 19 & 207 & 4,55 & 0,69 & 4,44 & 0,86 & 4,68 & 0,75 \\
\hline 20 & 207 & 3,32 & 0,98 & 3,31 & 1,06 & 3,16 & 1,07 \\
\hline
\end{tabular}

The tourists participating in the survey preferred areas where the structural arrangements for visitors such as Aydınpınar, OdayeriHighland and Efteni Lake were high. In the study, hydroelectric power plant areas that cause pressures on nature, construction images and natural areas without human intervention were not preferred visually, and the images with high structural arrangements for the visitors were highly preferred. It can be said that the existence of accommodation and recreation areas of regional architecture, monuments and historical objects is an important reason for 
visitors.

The preference evaluations of the tourists who participated in the survey based on the area were evaluated using One-way Analysis of Variance (ANOVA). The relationship between the area where the survey was made and the reasons to choose the area is given in Table 4.

Table4.One-Way Anova Analysis

\begin{tabular}{|c|c|c|c|c|c|c|c|}
\hline Variables & Area & $\mathbf{n}$ & Average & S.D. & Std. Error & $\mathbf{F}$ & Sig. \\
\hline \multirow{5}{*}{$\begin{array}{c}\text { Reasons for Preferring } \\
\text { the Area }\end{array}$} & Karasu & 53 & 4,11 & 1,79 & 0,24 & \multirow{5}{*}{5,27} & \multirow{5}{*}{0,002} \\
\hline & Akçakoca & 53 & 4,66 & 1,84 & 0,25 & & \\
\hline & Abant & 48 & 3,95 & 1,44 & 0,20 & & \\
\hline & Sapanca & 53 & 5,05 & 1,09 & 0,15 & & \\
\hline & Total & 207 & 4,45 & 1,62 & 0,11 & & \\
\hline \multirow{5}{*}{ Preferred Destination } & Karasu & 53 & 1,95 & 2,67 & 0,36 & \multirow{5}{*}{18,83} & \multirow{5}{*}{0,000} \\
\hline & Akçakoca & 53 & 2,60 & 2,59 & 0,35 & & \\
\hline & Abant & 48 & 4,91 & 1,98 & 0,28 & & \\
\hline & Sapanca & 53 & 4,16 & 1,67 & 0,22 & & \\
\hline & Total & 207 & 3,36 & 2,55 & 0,17 & & \\
\hline \multirow{5}{*}{$\begin{array}{l}\text { Whether they } \\
\text { participated in } \\
\text { ecotourism activities } \\
\text { in Uğursuyu and Aksu } \\
\text { Watersheds }\end{array}$} & Karasu & 53 & 1,75 & 0,43 & 0,05 & \multirow{5}{*}{7,45} & \multirow{5}{*}{0,000} \\
\hline & Akçakoca & 53 & 1,32 & 0,47 & 0,06 & & \\
\hline & Abant & 48 & 1,56 & 0,50 & 0,07 & & \\
\hline & Sapanca & 53 & 1,58 & 0,49 & 0,06 & & \\
\hline & Total & 207 & 1,55 & 0,49 & 0,03 & & \\
\hline \multirow{5}{*}{$\begin{array}{c}\text { Participation of } \\
\text { Activity }\end{array}$} & Karasu & 53 & 1,58 & 1,27 & 0,17 & \multirow{5}{*}{11,13} & \multirow{5}{*}{0,000} \\
\hline & Akçakoca & 53 & 2,69 & 2,11 & 0,29 & & \\
\hline & Abant & 48 & 1,64 & 1,99 & 0,28 & & \\
\hline & Sapanca & 53 & 1,58 & 2,03 & 0,27 & & \\
\hline & Total & 207 & 1,62 & 2,07 & 0,14 & & \\
\hline
\end{tabular}

When examined Table 4; ANOVA table of the values in the (significance) column are less than $0.05(p<0,05)$; therefore, the reasons for choosing the area they come from, the type of destination they prefer, whether they have been participated in ecotourism activities in the Uğursuyu and Aksu watersheds, have shown a statistically significant difference. The Tukey test was used to determine the source of this 
significant difference.

There is a statistical relationship between the fact that whether tourists have previously participated in ecotourism activities in the Uğursuyu and Aksu watersheds and where the destination of the survey. Akçakoca has the most tourists who participated in ecotourism activities in Uğursuyu and Aksu watersheds. This ranking is followed by Abant, Sapanca and Karasu.Tourists in Karasu have almost never participated in ecotourism activities in our study area. Although Abant is closer to the study area as a distance, transportation between Akçakoca and the study area is higher than other destinations. Tourists visiting Akçakoca are also expected to visit the ecotourism areas in the study area.

When the relationship between the type of activity they participated in the Uğursuyu and Aksu watersheds and the area in which the survey was answered, it was observed that the tourists in Akçakoca preferred more hiking. Although there are walking-tracks in the Akçakoca district, it is observed that the walking-tracks that include Güzeldere and Samandere Waterfalls, are especially recognized and attracted by tourists.

\section{Conclusion}

As a result of the survey based on photographic presentation applied to the users within the scope of the study, the results have been obtained which could guide the planning and management of the ecotourism destinations in the study area and their relation with the regional identity and culture.

The tourists participating in the survey, primarily in the sea-preferred destinations, then the forest, highland, waterfall and lake have been found to prefer the destination. This shows that the interest in sea tourism in our country is not diminishing, but alternative tourism types aiming to experience nature experiences are close to the competitive level with sea tourism. At this point, it is important to develop an effective image for the areas to increase the preferability of ecotourism areas in the study area.

When the visual preferences of the surveyed tourists are evaluated, it is clearly observed that the areas which caused destruction on the nature such as hydroelectric power plant, construction etc. haven't been preferred and that tourism destinations have lost their appeal. In addition to this; it is stated that the tourists find the photos of human elements are safe, prefer the photos that include accommodation and activity facilities, and do not prefer the natural areas where there are no buildings. 
The most preferred destinations have been "Abant Destination" and "Through Advice".According to the observations during the survey, Abant destination has been well-maintained and well-managed area where sub-superstructure services are available, providing activity options for users to spend quality time. In Uğursuyu and Aksuwatersheds, sub-superstructure studies should be done in ecotourism destinations as well, necessary precautions should be taken in ecotourism and recreation sources for protection and management, and loss of sensitive landscapes should not be caused. Cultural pattern, visual and ecological quality should not be underestimated during the construction works in ecotourism destinations.

Participants stated that they would prefer to participate in ecotourism activities in these areas after seeing the photographs. In addition, tourists from Abant and Akçakoca, which are the closest destinations to the study area, have orally stated that they can come to see the same distance when they come from Istanbul or Ankara. The fact that they have no knowledge of the ecotourism destinations in the Uğursuyu and Aksu watersheds has the result of theinadequate presentation and market activities. It will be useful to design a web site in such a way as to reflect the cultural landscape and regional identity of the study area and to make it possible for potential tourists to easily access the information they want, including current and accurate information.

Ecotourism is a sector that needs intensively natural and cultural resources and uses them as inputs in the development of the local people and the protection of regional identity properties. The sustainability of ecotourism depends on the cultural environment as well as the natural identity of the region. Considered from the tourist perspective; Cultural landscapesadd value to the experience of the tourists, increase the attractiveness of the destination, increase the residence time and expenses of the tourists in the region, and improve the loyalty of the tourists and make them visit the area again.Evaluation of cultural landscape in ecotourism from the perspective of local people; is an improvement of employment and quality of life, revival of agriculture and animal husbandry, development of awareness of protection of regional identity, sustainable competition for destination.

\section{Acknowledgement}

This paper supported by Düzce University Scientific Research Projects Coordinatorship (DÜBAP), Project number: BAP-2013.02.01.134. 


\section{References}

Akten, M. (2003).Determination of The Existing Potentials of Some Recreational Areas in Isparta Province. SüleymanDemirel University Journal of Forestry Faculty, A/2, ISSN: 1302-7085, 115-132.

Baloglu, Ş., Mangaloglu, M. (2001).Tourism destination images of Turkey, Egypt, Greece and Italy as perceived by US-Based tour operators and travel agents, Tourism Management, 22(1),1-9.

Beyhan, Ş.G., Ünügür, S.M (2005).Model of Sustainable Tourism and Identity in The Context of Cultural Continuity and Contemporary Requirements.Journal of ITU/A Architecture, Planning, Design, Vol:4/2, 79-87.

Bulut, Z. (2006).The Evaluation of Recreational Tourism Potential of Kemaliye (Erzincan) And Nearby Within an Alternative Tourism Framework. Atatürk University, Natural and Applied Sciences, Ph.D. Thesis, Erzurum/Turkey.

Chen, C., Tsai, D. (2007). How destination image and evaluative factors affect behavioral intentions?,Tourism Management, 28(4), 1115-1122.

Çalışkan, O. (2013). Gastronomic Identity in Terms of Destination Competitiveness and Travel Motivation. Journal of Tourism and Gastronomy Studies, 1(2), 39-51.

Duran, E. (2011). The Relationship Between Tourism, Culture and Identity, Sustainability of Social and Cultural Identity.Istanbul Commerce University Journal of Social Sciences, 10/19, 291-313.

Haven-Tang, C., and Jones, E.,(2006). Using Local Food and Drink to Differentiate Tourism Destinations Through a Sense of Place.Journal of Culinary Science \& Technology, 4 (4), 69-86.

İnan E. A., Akıncı S., Kıymalıoğlu A., Akyürek M. S., (2011). The Impact of Destination Image on Recommendation Among Cruise Passengers. Journal of Ege Academic Review. 11(3), 487-497.

Kıroğlu, E.(2007).Assessment of Some Recreation Areas in Erzurum City and its Neighbourhood in Point of Visual Landscape Quality.Atatürk University, Natural and Applied Sciences, MS Thesis, Erzurum/TURKEY.

Gültekin, P., Gültekin, Y.S. (2018). The Role of Festivals for Increasing the Attractiveness of Ecotourism Example of Düzce.Il. Internatinal Rural tourism and Development Congress, Bodrum-Muğla/TURKEY.

Müderrisoğlu H., Gültekin P.(2013).Understanding the children's perception and preferences on nature-based outdoor landscape.Indoor and Built Environment. 
Müderrisoğlu H., Uzun S. (2004). Recreational Tendencies of Students at Forestry Faculty, AbantlzzetBaysal University. SüleymanDemirel University Journal of Forestry Faculty, A/2, ISSN: 1302-7085, 108-121.

Ooi, C.C. (2004). "Poetics and Politics of Destination Branding: Denmark", Scandinavian Journal of Hospitality and Tourism, 4 (2), 107-128.

Önem, A.B. (2004). Urban Identity and Environmental Perception: A Case Study for Halic. Istanbul Technical University, Institute of Science and Technology, Ph.D. Thesis,istanbul/Turkey.

Özdemir, G. (2007).Destination Management and Fundamentals of Destination Marketing: A Model Proposal for The Destination İzmir. DokuzEylul University Institute of Social Sciences. Ph.D. Thesis, İstanbul/Turkey.

Özgüç, I.M. (1999).Visual Researches on Landscape PLANNING OF tem Between Hadımköy and Kınalı. Istanbul University, Institute of Science, Ph.D. Thesis, ístanbul/Turkey.

Özhancı E., Yılmaz H. (2013). Photo Safari Oriented Visual Landscape Analysis of The Mountains Reserving Different Landscape Characters, Atatürk University, Journal of the Agricultural Faculty, 44 (1): 83-89.

Özhancı E., Yılmaz H. (2011).Evaluation of Recreation Areas for Visual Landscape Quality; Sample of Erzurum, Iğdır Univ. J. Inst. Sci. \& Tech. 1(2): 67-76.

Özhancı E., Yılmaz H. (2012). Perception of Seasonal Change in Plant Designs by University Students. Architectonica, 1(1), 23-31.

Roovers, P., Hermy, M., Gulinck, H., (2002). Visitor profile, perceptions and expectations in forest from a gradient of increasing urbanization in central Belgium. Landsc. Urban Plan., 59, 129-145.

Seçilmiş C.(2011).The Problems That Affect the Development of Eskişehir's Tourism from the Visitors' Perspective. Journal of Business Research-Turk, 3/3 37-57.

Sevim B., Seçilmiş C., Görkem O. (2013).The Effect of Perceived Destination Image on The Attitude of Recommendation: A Research in Safranbolu. Journal of Management Economics and Business, Vol. 9, No. 20, 115-129.

Som A., Shirazi S., Marzuki A., Jusoh J. (2011).A critical analysis of tourist satisfaction andDestination Loyalty, Journal of Global Management, 2(1), 78-183.

Uzun, O., Gültekin, P., Gültekin, Y.S., Özdede, S., Kaya, S. (2016). Evaluation ofEcotourism Cultural Landscape Pattern in Uğursuyu and Aksu 
Watersheds.Duzce University Scientific Research Project, Project Number: 2013.02.01.134.

Yosmaoğlu, N., Engin, F. (2002). Düzce Provincial Development Plan Services Sector Report, http://www. duzce.gov.tr/dosyalar/digp/digp_hizmetler_raporu.pdf.

Ziffer, K. (1989). Ecotourism: The Uneasy Alliance, Conservation International, Ernst and Young, Washington DC. 